\title{
Vegetation structure and ecological characteristics of forest of North Andaman Islands (India)
}

\author{
P. RAMA CHANDRA PRASAD ${ }^{1 *}$, A. N. SRINGESWARA ${ }^{2}$, C. SUDHAKAR REDDY ${ }^{3}$, \\ P. VIJAYA KUMARI ${ }^{4}$, R. K. VARALAKSHMI ${ }^{5}$, S. H. RAZA ${ }^{6}$ and C. B. S. DUTT ${ }^{7}$
}
${ }^{1}$ Laboratory for Spatial Informatics, International Institute of Information Technology, Gachibowli, Hyderabad-500032, India, Tel: +91 92 46109160. Fax: +91 406653 1413; e-mail:rcprasad@iiit.ac.in,rcp_ncmsl@yahoo.co.in
${ }^{2}$ Department of Forestry and Environmental Science, University of Agricultural Sciences, GKVK Campus, Bangalore-560065, India
${ }^{3}$ Forestry and Ecology Division, National Remote Sensing Agency, Department of Space, Balanagar, Hyderabad-500037, India
${ }^{4}$ Department of Botany, Bhavan's New Science College, Hyderabad-500029, India
${ }^{5}$ Department of Botany, V. V. College of Science, Hyderabad- 500195, India
${ }^{6}$ Aurora's Scientific Technological \& Research Academy, Bandlaguda, Hyderabad-500005, India ${ }^{7}$ Indian Space Research Organization, Department of Space, Anthariksh Bhavan, Bangalore-560094, India. * Correspondence author

(Received on 9 June 2008; Accepted on 8 November 2009)

\begin{abstract}
In this study, 3-ha research plots were established, one each in evergreen, semi-evergreen, and moist deciduous forests of North Andaman Islands. These 3 vegetation types were selected to study the structural aspects of plant diversity in forest communities. Our results showed high species richness and basal area in evergreen forest, high diversity in semi-evergreen forest, and high tree density (trees ha ${ }^{-1}$ ) in moist deciduous forest. At family level, the Anacardiaceae and Sterculiaceae dominated all the forest types, and were distributed throughout the North Andaman Islands. In the 3 forest communities, most species exhibited clumped spatial distribution, while random distribution ranked second. Tree girth class distribution revealed a decreasing number of trees with increasing girth class, indicating natural regeneration of these forest types. The species-area curve clearly reached a plateau at 3-ha area in respect of species number, supporting the adequacy of the large plot size selected in the present investigation. The study recorded a total of 136 tree species in the 3 forest communities and was higher than in many other tropical forest sites. The vegetation analysis of 3-ha plot in 3 different forest types substantially contributed data on North Andaman site potentiality, with reference to its species richness and diversity.
\end{abstract}

Keywords: ecological niche, spatial distribution, plant diversity, forest community, island vegetation

\section{INTRODUCTION}

Variation in the structural and functional aspects of forest vegetation across the world is mainly due to the wide topographic barriers (BORCARD et al. 1992, RUOKOLAINEN et al. 1997, VAlencia et al. 1994), climate (Murphy \& Lugo 1986, Blasco et al. 
2000, Parthasarathy et al. 2008), and edaphic factors of the region (TuOmisto et al. 2003). The product of these variations is the emergence of various vegetation types that differ in species richness and diversity. Alternatively, the differences in species diversity profiles among various vegetation units can be explained using ecological theories related to environmental heterogeneity (TERBorgh et al. 1996, CLARK et al. 1998) or to the dispersal limitation of the species within a given vegetation type (HubBell et al. 1999).

The dissimilarity in vegetation structure and ecological attributes is more distinct when a comparison is made between continuous mainland and isolated bay islands. The theory of island biogeography explains that the type of species and their number are totally different on isolated islands, where the species immigration rates are low and extinction rates are high (MACARTHUR \& WILSON 1967). Island vegetation studies (Stewart 1986, Allen et al. 1994, JACOBS et al. 1997, EMPSON et al. 2002) are inquisitive and deal with species composition, survival, sustainable capacities, and the way in which plants adapt to the changing geographical conditions to maintain dynamic vegetation. Within these isolated bay islands, species undergo the process of speciation (JONATHAN et al 2004, COYNE \& ORR 2004, White 1978), resulting in the formation of a community that differs (in species composition and dominance) from the mainland communities (GRANT 1981).

Plants growing in a community are inter-related with one another and with the environment in which they live. Species composition, assemblage structure, and distribution patterns of species define the nature and type of forest community (ELAINE et al. 2004). Vegetation descriptors - such as species richness, density, and basal area - are often used to describe the structure of forest communities (BATALHA et al. 2001, VALENCIA et al. 1994). These descriptors are put together as complex measures of plant diversity, which is generally described as a composite property that reflects both the number of species (richness) in a biological community and the evenness with which abundance is distributed among the different species (MYERs et al. 1995). The community-level studies of plant diversity can be made at various spatial scales (NEGi 2001), using vegetation descriptors. So far, the investigations have been mostly descriptive focusing on regional and global scales (GASTON 1996).

To understand better the plant diversity and investigate the structure, composition, and dynamics of vegetation, researchers have sampled large-scale permanent plots in various forest sites throughout the world, viz. Pasoh Forest Reserve, Malaysia (Manokaran et al. 1990); Barro Colorado Island, Panama (Condit et al. 1995); Huai Khae Khaeng, Thailand (Bunyavejchewin et al. 2001); Luquillo, Puerto Rico (Zimmerman et al. 1994, Thompson et al. 2002); Lambir, Borneo, Malaysia (LeE et al. 2002); Sinharaja World Heritage Site, Sri Lanka (GunAtilleke et al. 2004); Yasuni, Ecuador (Valencia et al. 1994); and Western Ghats, India (Parthasarathy 1988, Sukumar et al. 1992, Ganesh et al. 1996, Ayyapan \& Parthasarathy 1999, Pascal \& Pelissier 1996, Pascal et al. 1998). However, on Andaman and Nicobar Islands (ANI), large-scale studies are relatively rare, due to their remote and inaccessible nature. Nevertheless, in the recent past, vegetation of these islands was explored to reveal their unique species richness and diversity patterns (HITENDRA et al. 2004, RoY et al. 2005, Prasad et al. 2007; 2008; 2009, RAJKumar \& PARthasarathy 2008). 
The study of PRASAD et al. (2007), who surveyed random plots ( 0.1 ha size) in predominant forest types at various topographic gradients, provided a detailed account of the plant diversity of North Andaman Islands (NAI). That study captured the diversity profiles existing on NAI in relation to environmental heterogeneity. It was the basis for the present study, which aims to examine the patterns of vegetation parameters at homogenous conditions of large plots. The present research is similar to the large-scale plot sampling (not permanent) done in various tropical forests globally, but first time for ANI. The objective of this research is to analyze homogenous forest vegetation by investigating the structural aspects of plant diversity in large plots (3-ha) where topographic and edaphic factors are largely similar. The study provides detailed ecological characteristics of vegetation structure of NAI and aids in understanding the spatial distribution of vegetation descriptors for biodiversity conservation and management. This type of large-scale study was unique on NAI, where 3 forest types were examined, unlike in other large-scale studies (globally) that are mostly concentrated on evergreen forests and very few on other forest types.

\section{Study area}

ANI are among the major biodiversity eco-regions (Indo-Burma hotspot) in the world (WiKRAMANAYAKE et al. 2002, KRUPNICK \& KRESS 2003). Like other parts of the archipelago, NAI $\left(12^{\circ} 95^{\prime} \mathrm{N}, 92^{\circ} 86^{\prime} \mathrm{E}\right.$, Fig. 1) are characterized by a high endemicity and species diversity (PRASAD et al. 2007). These tropical islands, with rainy sum-

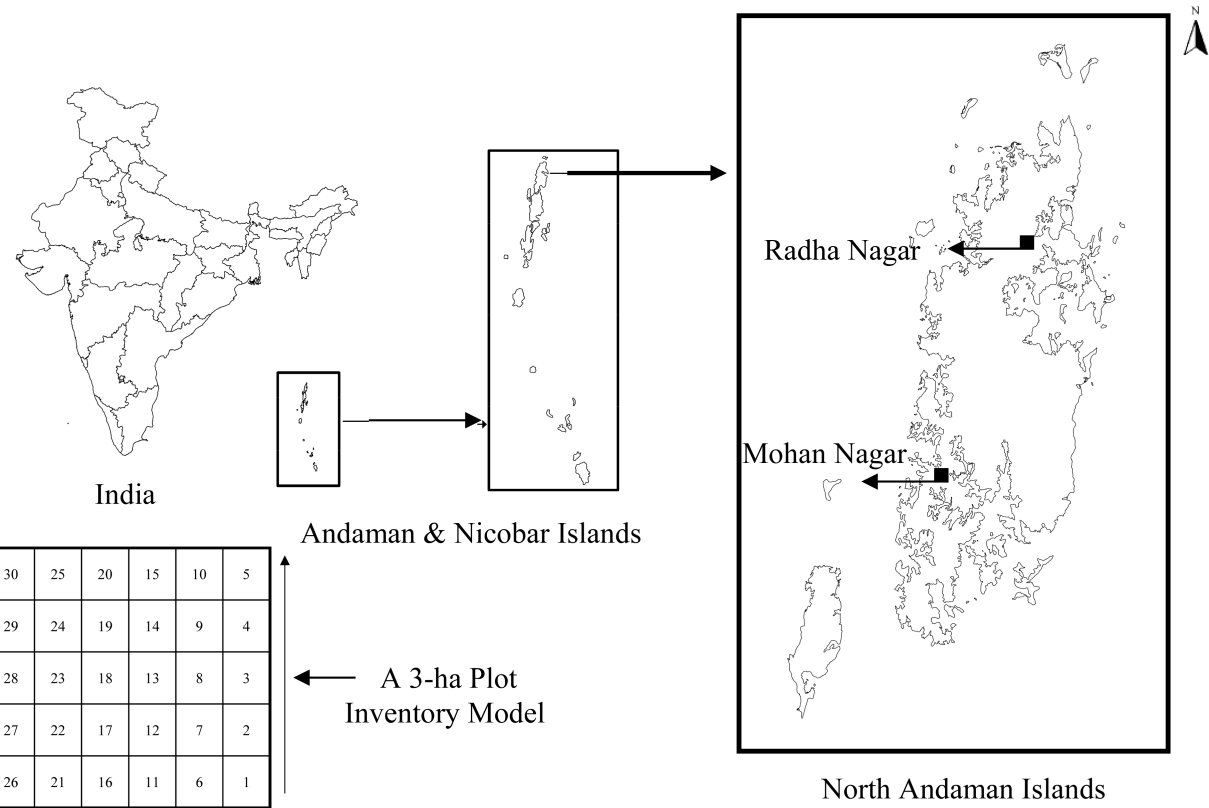

Fig. 1. Location map of North Andaman Island 
mers, receive rainfall almost throughout the year, under the influence of south-west and north-west monsoons. Topography is undulating, with hill ranges and narrow valleys. Soils are mostly acidic, poor in organic carbon and nitrogen (DEVARAJ 2001). The existence of various forest types within the study area is due to micro topographic and soil variations. They give the scenario of hilltop evergreen forest (EG) forest and lowland moist deciduous (MD) forest, with scattered semi-evergreen forest (SEG) throughout the islands. Irrespective of forest type, the vegetation is dense, with rattans, climbers, shrubs, and herbs.

\section{MATERIALS AND METHODS}

The plots (3-ha size) were laid out at 2 locations: EG plot at Mohan Nagar, while SEG and MD at Radha Nagar (Fig. 1), in relatively natural patches. Each 3-ha plot $(158 \mathrm{~m} \times 1900 \mathrm{~m})$ was divided into 30 subplots of 0.1 ha each, for systematic survey. In each subplot, all trees $>30 \mathrm{~cm}$ gbh (girth at breast height, $1.3 \mathrm{~m}$ ), as well as shrub, herb, and climber data were enumerated and analyzed. Tree height was also measured.

\section{Data analysis}

Vegetation structure of the forests has been described in the present study mostly on the basis of data on tree species of $>30 \mathrm{~cm}$ gbh (girth at breast height). For each tree species, we calculated: density $(=100 \times$ total number of individuals of a species / total number of subplots sampled); frequency (=100 $\times$ number of subplots with the species / total number of subplots sampled); abundance $(=100 \times$ total number of individual of species in all subplots / total number of subplots in which species occurred), basal area $=(\mathrm{gbh})^{2} / 4 \pi$ (total area occupied by stems at breast height, $\left.1.3 \mathrm{~m}\right)$; relative frequency $(=100 \times$ frequency of the species / sum of frequency of all the species), relative density (= $100 \times$ density of the species / sum of density of all the species), and relative dominance $(=100 \times$ total basal area of the species / total basal area of all the species).

Next, the importance value index (IVI) was calculated as the sum of relative frequency, relative density and relative dominance (COTTAM \& CURTIS 1956). Based on the IVI values, the predominant species were considered as representatives of vegetation types. Diversity, evenness, concentration of dominance, and species similarity among vegetation types were computed using Shannon (SHANNON \& WEAVER 1963), Hill evenness (Hill 1973), Simpson (SimPSON 1949) and Sorensen similarity indices (SORENSEN 1948), respectively. Abundance to frequency ratio was used to determine the spatial pattern of species: regular for values $<0.025$, random for values between 0.025 and 0.05 , and clumped/contiguous for values $>0.05$ (COTTAM \& CURTIS 1956). Girth class frequency distribution was analyzed for species richness, diversity, density, and basal area. Species-area curve was constructed on the basis of data for individual 0.1 ha subplots. The spatial distribution of species richness, diversity, tree density, basal area, and mean height are represented as surface charts, using the surface chart function of Microsoft Excel 2000 (adopted from DeBsKi et al. 2000). 


\section{RESULTS}

Analysis of the similarity index indicates that more than $50 \%$ of species were shared by the 3 forest types (EG-SEG 67\%, SEG-MD 68\%, and EG-MD 59\%). Further results of vegetation analysis of each 3-ha plot depicted the vegetation structure and ecological characteristics of each forest type as follows.

\section{Evergreen community}

Overall, we recorded 1544 trees with $>30 \mathrm{~cm}$ gbh, belonging to 93 (including 4 unidentified) species, 67 genera, and 36 families. Of the 93 species, 23 are endemic, 30 are singletons (i.e. represented by only one tree in the 3-ha plot) and 11 are doubletons (two trees in 3-ha plot). The most numerously represented genera were Dipterocarpus, Myristica, and Aglaia, contributing 4 species each. Species richness amounted to 31 species $\mathrm{ha}^{-1}$. Shannon diversity, Simpson index, and Hill evenness were $4.8,0.07$, and 0.70 , respectively. Within the tree girth classes, species richness and diversity decreased from lower to higher girth class. Girth class 30-60 $\mathrm{cm}$ showed high species richness (66 species out of 93), with 20 unique species exclusively recorded in that class, while high diversity (4.6) was observed in girth class 60-90 cm.

Tree density recorded for various species ranged from 1 (for 30 species) to 231 trees (for Myristica andamanica) per plot (3-ha). The total tree density was 515 ha $^{-1}$ with $50 \%$ contributed by 5 species: M. andamanica $\left(15 \%, 77 \mathrm{ha}^{-1}\right)$, Pterygota alata $\left(12.2 \%, 63 \mathrm{ha}^{-1}\right)$, Dipterocarpus grandiflorus $\left(11.3 \%, 58 \mathrm{ha}^{-1}\right)$, Celtis wightii $\left(6.8 \%, 35 \mathrm{ha}^{-1}\right)$ and Pterospermum acerifolium $\left(6.0 \%, 31 \mathrm{ha}^{-1}\right)$. Girth class frequency distribution shows that $70 \%$ of the total tree density is formed by girth classes $30-60 \mathrm{~cm}(44 \%)$ and 60-90 cm (26\%). The total basal area amounted to $43.2 \mathrm{~m}^{2} \mathrm{ha}^{-1}$ and $50 \%$ of basal area was contributed by D. grandiflorus $(14 \%)$, M. andamanica (11\%), Pometia pinnata (10\%), Pterygota alata (9\%), and Xanthophyllum andamanicum $(6 \%)$. The basal area contribution by girth classes showed an intermittent trend of decreasing and increasing values, with a maximum contribution by girth class $>210 \mathrm{~cm}(31 \%)$.

Out of 1544 trees, $56 \%$ were within the height class $5-10 \mathrm{~m}, 36 \%$ in class $10-15 \mathrm{~m}$, and $8 \%$ in class $>15 \mathrm{~m}$. The IVI values showed that 10 species contributed 56\% of IVI, mostly Myristica andamanica and Dipterocarpus grandiflorus. Out of 37 families, the Anacardiaceae with 9 species (in 3-ha plot), Myristicaceae and Sterculiaceae with tree density of 108 and 105 trees ha $^{-1}$, respectively, and Dipterocarpaceae accounting for $19 \%$ of total basal area can be treated as predominant. The spatial distribution of species showed a regular pattern for one species, random for 14 species, and clumped for the majority. In overall analysis of the entire 3-ha plot, $M$. andamanica dominated the plot and is described as a key species of the site.

Species richness within the subplots varied from 9 (subplots 1 and 30) to 28 species (subplot 26), species diversity from 2.2 ( $1^{\text {st }}$ subplot) to 4.3 (subplot 26), tree density from 24 (subplot 2) to 88 trees (subplot 19), and basal area from 2.2 (subplots 2 and 10 ) to $8.7 \mathrm{~m}^{2}$ (subplot 9), with mean tree height from 7.9 (subplot 14) to 13.3 m (subplot 9). 


\section{Semi-evergreen community}

A total of 1461 trees belonging to 82 species, 62 genera, and 36 families were recorded in 3-ha plot. Among 82 species, 12 are endemic, 11 are singletons and 7 are doubletons, with species richness of 27 species ha-1. Diospyros (with 6 species) and Aglaia (with 4 species) were the best-represented genera. Shannon diversity, Simpson index, and Hill evenness were 5.5, 0.03, and 0.86, respectively. Girth class 30-60 cm recorded high species richness ( 70 species out of 82 ), with 12 unique species, along with a high diversity (5.3), and both the parameters decreased in the higher girth classes.

Tree density ranged from 1 (for 11 species) to 110 trees (for Myristica irya) per plot (3-ha). The total tree density was $487 \mathrm{ha}^{-1}$ with 5 species contributing $25 \%$ of tree density: $M$. irya $\left(7.5 \%, 37\right.$ trees ha $\left.{ }^{-1}\right)$, Pterospermum acerifolium $\left(5.7 \%, 28 \mathrm{ha}^{-1}\right)$, Pterocarpus dalbergoides $\left(5 \%, 23 \mathrm{ha}^{-1}\right)$, Dipterocarpus gracilis $\left(4.1 \%, 20 \mathrm{ha}^{-1}\right)$, and Celtis wightii $\left(4 \%, 20 \mathrm{ha}^{-1}\right)$. Girth class distribution showed a decreasing trend, with more trees in lower classes, except in girth class $>210 \mathrm{~cm}$, where the number of trees increased. Girth classes 30-60 $\mathrm{cm}(52 \%)$ and $60-90 \mathrm{~cm}(22 \%)$ represented $74 \%$ of the total tree density of the plot.

Basal area reached $36.87 \mathrm{~m}^{2} \mathrm{ha}^{-1}$ and 5 species contributed $45 \%$ of the basal area: Pterocarpus dalbergoides (15\%), Dipterocarpus gracilis (10\%), Artocarpus chaplasha $(8 \%)$, Tetrameles nudiflora $(8 \%)$, and Terminalia procera $(4 \%)$. The basal area within girth classes showed that much of the total basal area of the plot was contributed by the extreme classes, i.e. $30-60 \mathrm{~cm}(10.4 \%)$ and $>210 \mathrm{~cm}(36.2 \%)$. Height class distribution was similar to the EG type, and $62 \%$ of trees were in the height class of $5-10 \mathrm{~m}, 36 \%$ in class $10-15 \mathrm{~m}$, and only $2 \%$ were over $15 \mathrm{~m}$ tall. A regular decrease in species IVI was observed, with 10 species contributing $45 \%$ of IVI of the total plot, dominated by Pterocarpus dalbergoides and Dipterocarpus gracilis. Among the 36 observed families, the Anacardiaceae with 9 species, Fabaceae contributing 15\% of total basal area, and Sterculiaceae represented by 62 trees ha ${ }^{-1}(13 \%$ of total tree density) can be treated as predominant. Out of 82 species, 23 exhibited a random pattern, while the remaining 59 showed clumped distributional patterns. Myristica irya was the most important species of this forest type.

Species richness within subplots ranged from 12 (subplot 12) to 30 species (subplot 23), diversity from 3.1 (subplot 7) to 4.7 (subplot 10), while tree density from 20 (subplot 12) to 75 trees (subplot 23). Among the 30 subplots, the lowest basal area was recorded in subplot $12\left(1.1 \mathrm{~m}^{2}\right)$ and highest in subplot $17\left(6.4 \mathrm{~m}^{2}\right)$. Mean tree height ranged between 8 (subplot 4) and $10.8 \mathrm{~m}$ (subplot 16).

\section{Moist deciduous community}

The 3-ha plot inventory within the low-lying MD forest showed 1567 trees of 73 species (one unidentified), 58 genera, and 27 families. Among the 73 species, 11 are endemic, 14 are singletons and 9 are doubletons. Like in SEG, Diospyros and Aglaia were the most important genera, contributing 4 species each. Diversity indices showed values of 4.8 for Shannon, 0.07 for Simpson, and 0.76 for Hill evenness indices, with species richness of 24 species $\mathrm{ha}^{-1}$. Species richness showed a decreasing trend in tree girth classes, with the highest species richness contributed by girth class 
30-60 cm (65 species out of 73, with 17 unique species), and similarly to EG, girth class 60-90 cm exhibited a high diversity (4.5).

Tree density of various species ranged from 1 (for 14 species) to 321 trees per plot (for Diospyros oocarpa). Tree density was $522 \mathrm{ha}^{-1}$, with $45 \%$ of the total represented jointly by D. oocarpa $\left(20 \%, 107\right.$ trees ha $\left.{ }^{-1}\right), D$. kurzi $\left(7.4 \%, 39\right.$ ha $\left.^{-1}\right)$, Streblus asper $\left(6.6 \%, 35 \mathrm{ha}^{-1}\right)$, Celtis wightii $\left(5.9 \%, 31 \mathrm{ha}^{-1}\right)$ and Pterocarpus dalbergoides $\left(4.6 \%, 24 \mathrm{ha}^{-1}\right)$. Girth class distribution showed decreasing tree density up to $180-210$ $\mathrm{cm}$, but increased in $>210 \mathrm{~cm}$ class, with $80 \%$ of tree density represented by girth classes 30-60 cm (58\%) and 60-90 $\mathrm{cm}(22 \%)$.

Basal area was $35.39 \mathrm{~m}^{2} \mathrm{ha}^{-1}$ and $61 \%$ of the plot was occupied by Pterocarpus dalbergoides (31\%), Terminalia bialata (10\%), Diospyros oocarpa (8\%), Lannea coromandelica (6\%), and Tetrameles nudiflora (6\%). In relation to tree girth classes, $64 \%$ of total basal area is contributed by girth classes 30-60 cm $(12.8 \%), 60-90 \mathrm{~cm}$ $(12.9 \%)$, and $>210 \mathrm{~cm}(38.2 \%)$. With reference to height classes, a majority of the trees were under $10 \mathrm{~m}(63 \%)$ or $10-15 \mathrm{~m}(34 \%)$, and only $3 \%$ of trees were over $15 \mathrm{~m}$ tall. The IVI showed a gradual decreasing trend, with $58 \%$ of IVI represented by top 10 species, dominated by Pterocarpus dalbergoides and Diospyros oocarpa. Out of 27 families, the Anacardiaceae, Meliaceae and Sterculiaceae showed a species count of 6 each, which is low, compared with EG and SEG plots. The Ebenaceae with 30\% of total tree density of the plot, and Fabaceae with $32 \%$ basal area, dominated the site. The spatial distribution of species showed random patterns for 19 species and clumped pattern for the remaining 54 species. Diospyros oocarpa was considered as representative species of the community.

Species richness within the 30 subplots ranged from 12 (subplot 18) to 27 species (subplot 25) with species diversity from 2.3 (subplot 18) to 4.6 (subplot 25) and tree density from 22 (subplot 29) to 72 trees (subplots 12 and 16). Of the 30 subplots, subplot 28 had the lowest basal area $\left(1.2 \mathrm{~m}^{2}\right)$ and subplot 13 had the highest $\left(6.5 \mathrm{~m}^{2}\right)$, while mean height was between $7.6 \mathrm{~m}$ (subplot 26) and $11.1 \mathrm{~m}$ (subplot 1).

\section{Spatial analysis of vegetation parameters}

The spatial distribution of vegetation descriptors within each 3-ha plot of the 3 forest systems is shown as surface charts (Fig. 2). In EG, a majority of subplots showed species richness of 10-20 tree species, diversity values of 3-4, tree density of 40-60 trees, basal area of 4-6 $\mathrm{m}^{2}$, and mean tree height over $10 \mathrm{~m}$. In SEG, a majority of subplots showed species richness of 20-30 tree species, diversity values of 4-5, tree density of 40-60 trees, basal area of 2-4 $\mathrm{m}^{2}$, and mean tree height of 5-10 m. In $\mathrm{MD}$, species richness and diversity showed similar values as EG, while the other parameters followed the SEG pattern. The cumulative results of subplots of three 3-ha plots provide information on the lowest and highest levels of vegetation descriptors that can be encountered on NAI: i.e. 9-30 for species richness, 2.2-4.7 for diversity, and 24-75 for tree density (Table 1).

\section{Species-area curve}

The curves clearly showed a plateau for the area of 3-ha in respect of species number, supporting the adequacy of the plot size selected for the present investiga- 
Evergreen

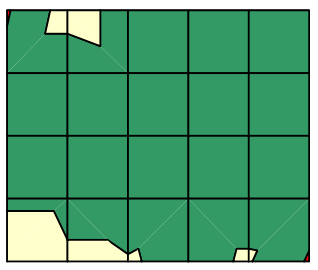

Species richness
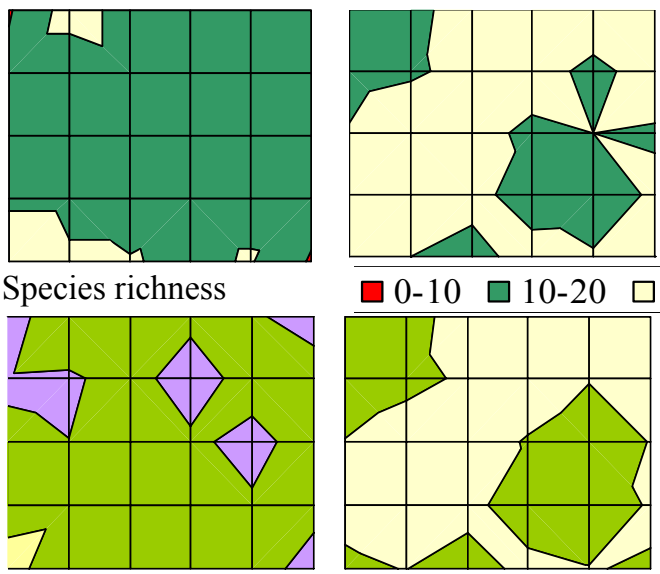

$\square$ 0-10 $\square 10-20 \quad \square 20-30$


Species diversity $\square$ 0.0-1.0 $\square$ 1.0-2.0 $\square$ 2.0-3.0 $\square$ 3.0-4.0 $\square$ 4.0-5.0
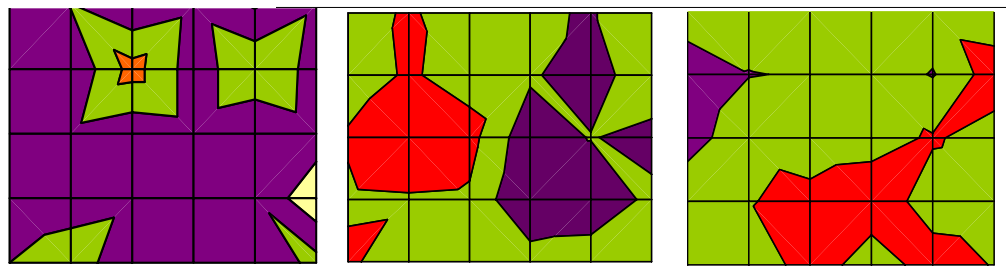

Tree density (number) $\square$ 0-20 $\square$ 20-40 $\square$ 40-60 $\square$ 60-80 $\square$ 80-100
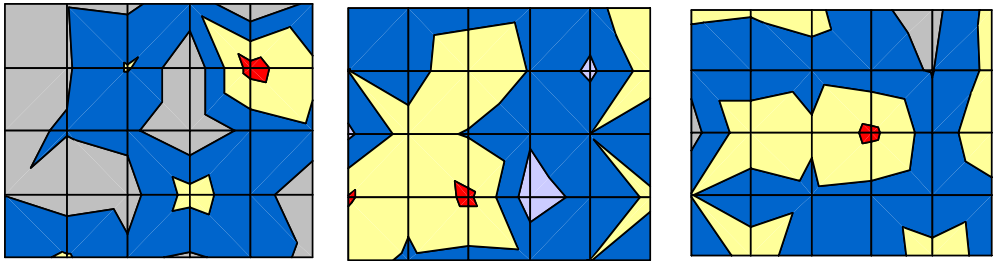

Basal area $\left(\mathrm{m}^{2}\right) \square$ 0.0-2.0 $\square$ 2.0-4.0 $\square$ 4.0-6.0 $\square$ 6.0-8.0 $\square$ 8.0-10.0



Mean height (m)
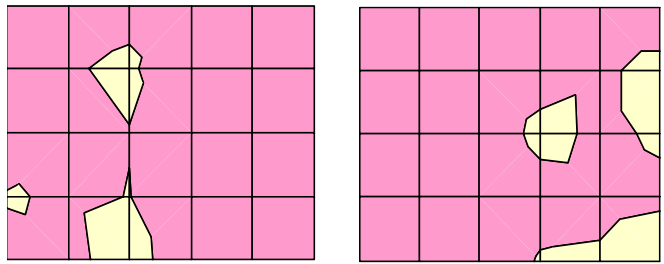

$\square 0.0-5.0 \quad \square 5.0-10.0 \quad \square 10.0-15.0$

Fig. 2. Surface charts showing spatial distribution of vegetation parameters in 3-ha plots of each forest type on North Andaman Island 


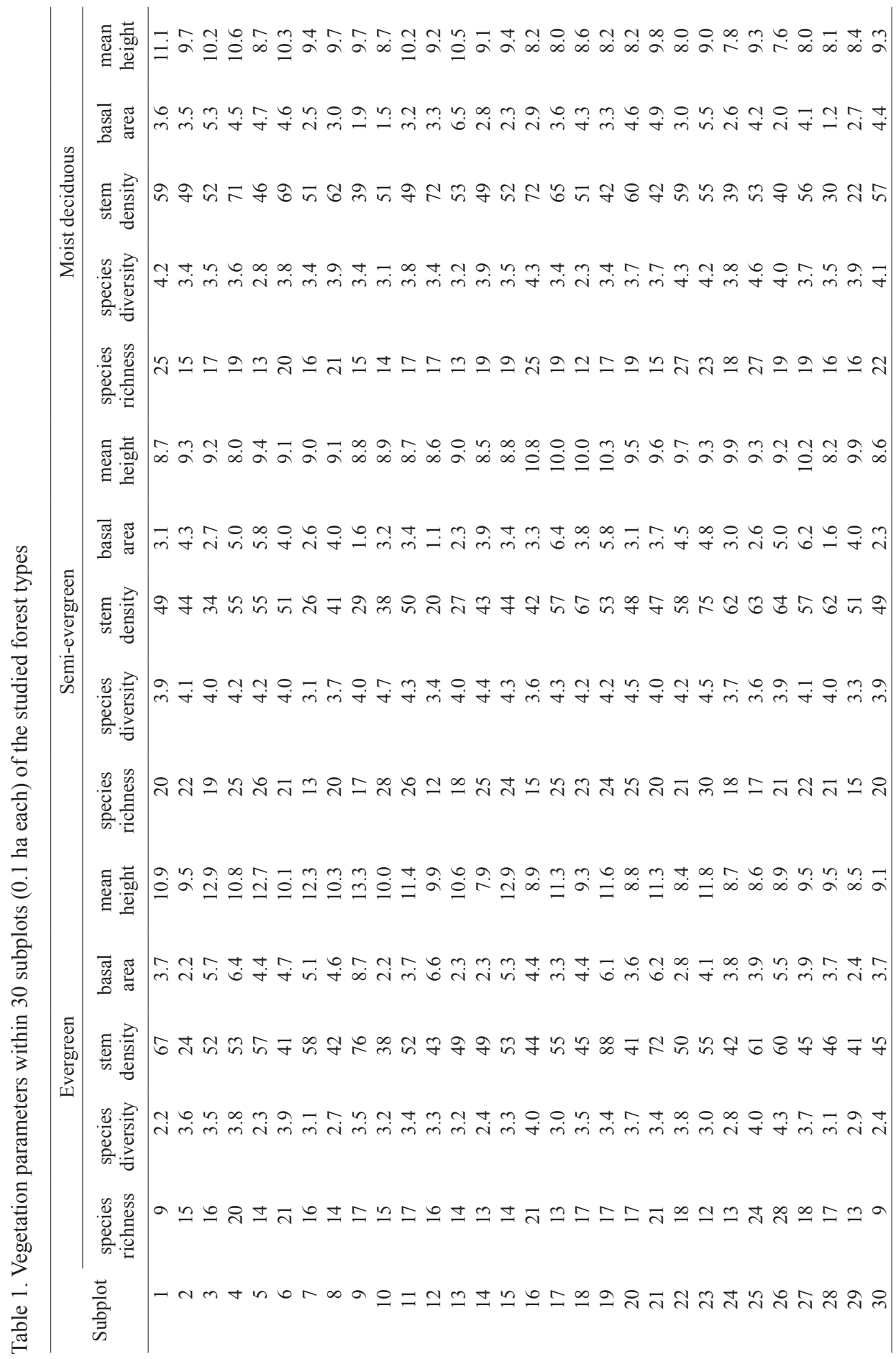




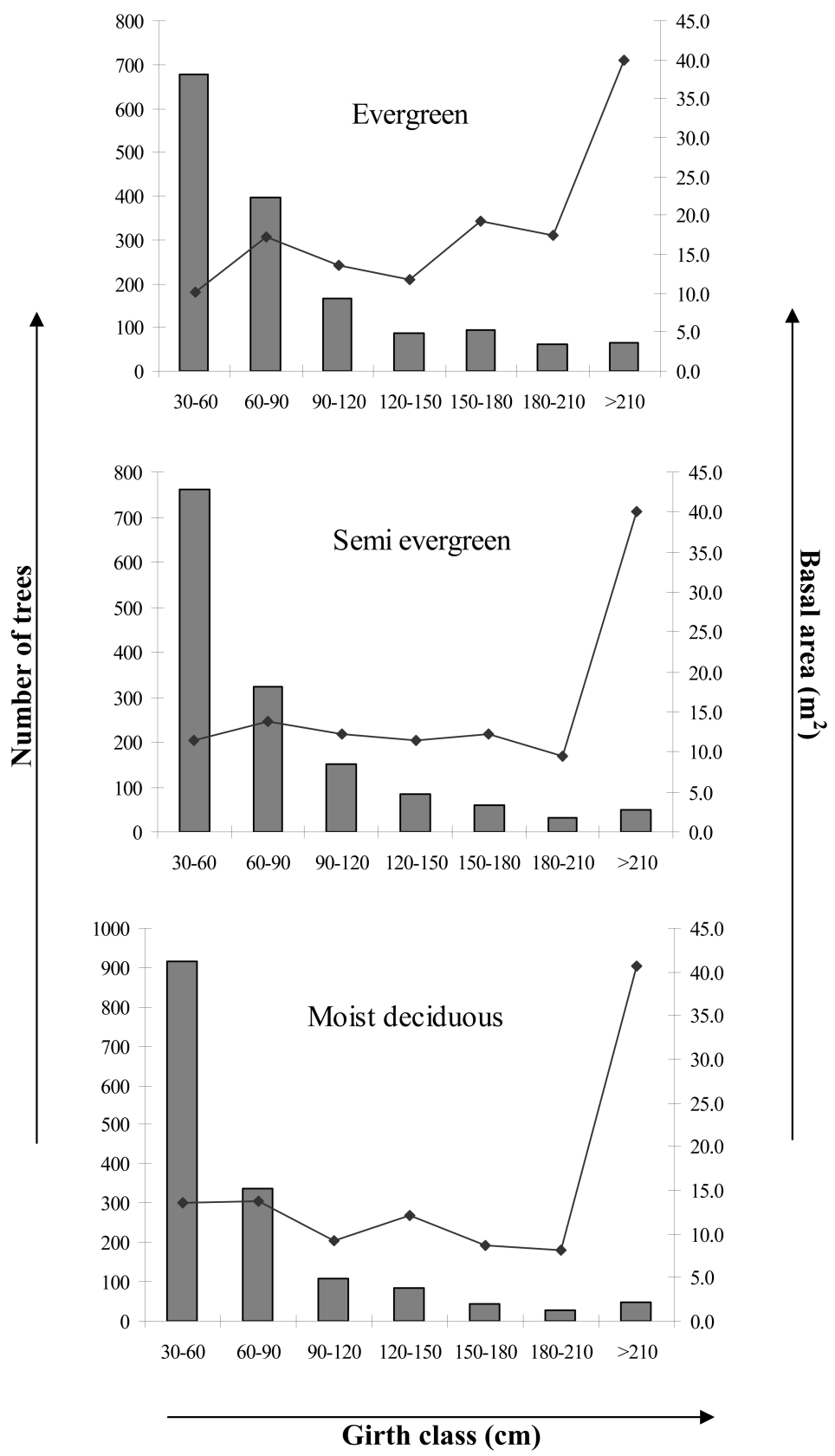

Fig. 3. Stem density and basal area in various girth classes in the studied forest types on North Andaman Island 


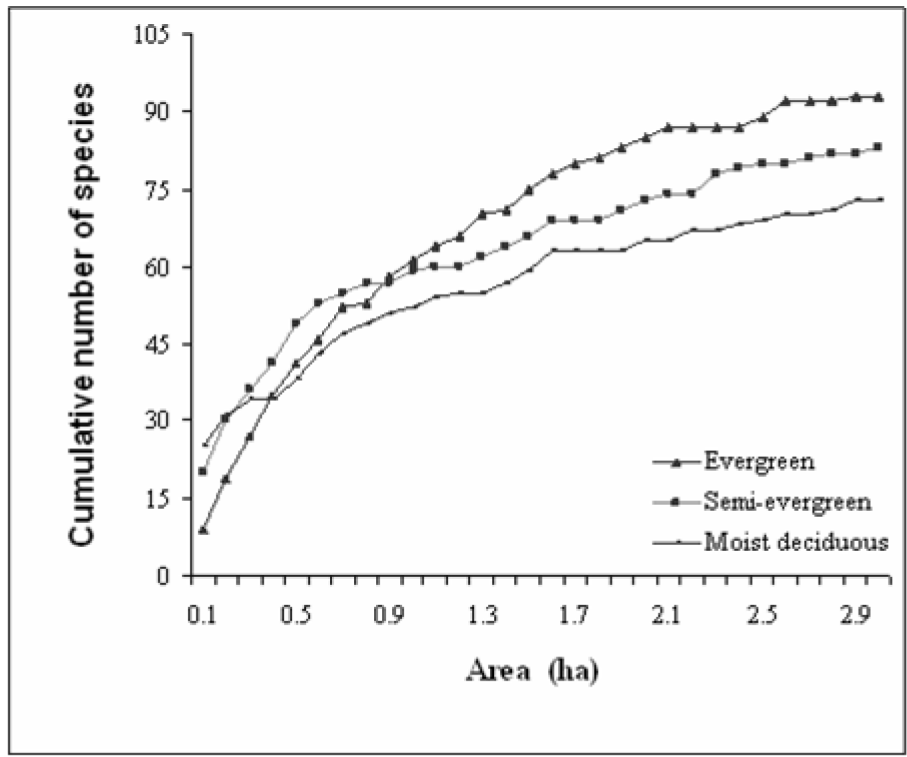

Fig. 4. Species-area curves of the studied forest types on North Andaman Island

tion (Fig. 4) and for the benefit of ambiguity it would be ideal for future investigations in areas larger than 3-ha. In the present study only tree species with $\mathrm{gbh}>30 \mathrm{~cm}$ were considered for plotting the graph, but if all the other plants were also included (Table 2: climbers, shrubs, and herbs), then probably the curve would also reach a plateau, capturing the required species number to represent the forest community. It is evident that lower groups contributed a good increase in species richness and elevated the species area curve, proving that the sampled area (3-ha) is adequate to analyze plant diversity in the community. Among the 3 forest communities, species diversity was the highest for climbers in EG (4.1), for shrubs in MD (2.4), and for herbs in SEG forest (3.1).

Table 2. Species richness and diversity in various plant groups in the studied forest types

\begin{tabular}{|c|c|c|c|c|c|c|}
\hline \multirow{2}{*}{ Plant group } & \multicolumn{2}{|c|}{ Evergreen } & \multicolumn{2}{|c|}{ Semi-evergreen } & \multicolumn{2}{|c|}{ Moist deciduous } \\
\hline & $\begin{array}{l}\text { species } \\
\text { richness }\end{array}$ & $\begin{array}{c}\text { species } \\
\text { diversity }\end{array}$ & $\begin{array}{l}\text { species } \\
\text { richness }\end{array}$ & $\begin{array}{c}\text { species } \\
\text { diversity }\end{array}$ & $\begin{array}{l}\text { species } \\
\text { richness }\end{array}$ & $\begin{array}{l}\text { species } \\
\text { diversity }\end{array}$ \\
\hline Climbers & 51 & 4.1 & 29 & 3.9 & 41 & 3.9 \\
\hline Shrubs & 9 & 2.0 & 10 & 2.0 & 13 & 2.4 \\
\hline Herbs & 13 & 2.4 & 11 & 3.1 & 12 & 1.8 \\
\hline Total & 73 & & 50 & & 66 & \\
\hline
\end{tabular}




\section{DISCUSSION}

The highest species richness (93) was recorded for EG, and this is mainly contributed by the higher percentage (44\%) of rare species (singletons and doubletons). However, diversity was greater in SEG, with low concentration of dominance and high evenness values, which indicate heterogeneous nature and equal dominance of species within the community. These results followed similar trends as observed in a random sampling inventory by PRASAD et al. (2007). Four genera - Dipterocarpus, Myristica, Diospyros and Aglaia - played a vital role in enhancing the species richness of North Andaman forest. The high percentage of species similarity between the 3 forest types indicates the close ecotonal gradients among vegetation types, thus allowing maximum sharing of species to form a community represented by a mixture of EG and MD species.

The tree species richness of EG recorded in the present study (93 species) is greater than in the inventories conducted at Kalakad-Mundandurai Tiger Reserve $(90$ species / 3.82 ha - GANESH et al. 1996) and Uppangala forest (90 species / 3.12 ha - Pascal \& Pelissier 1996) of Western Ghats. The species richness recorded by PARTHASARATHY et al. (2008) in tropical dry evergreen forest along Coromandel Coast, India, by surveying 75 sites (ranging in size from 0.5 to 10 ha) recorded tree species richness between 10 and 69, which is also low with respect to SEG (82) and MD (73) in the present study area. The species richness of MD (24 species ha-1) is found to be high with reference to the tropical EG inventory of Varzea forest RioXingu, Brazil (20 species ha ${ }^{-1}-$ CAMPBELl et al. 1992) and tropical deciduous forest of Mudumalai, India (22 species ha-1 - SuKUMAR et al. 1992). The EG richness ( 31 species ha $^{-1}$ ) is similar to that observed in Nelliampathy, Western Ghats (30 species ha ${ }^{-1}-$ CHANDRASHEKARA \& RAMAKRISHNAN 1994) and low with reference to the Courtallum reserve forest, Western Ghats (57 species ha ${ }^{-1}$ - PARThasarathy \& KarThiKeyAn 1997).

The total of 136 tree species recorded from the 3 plots (total 9-ha area) of the present research, is higher than in other studies, such as 63 species from a 50- ha plot at Mudumalai (SuKumar et al. 1992) and 103 species from a 28-ha plot at Uppangala (PAscal \& Pelissier 1996), but slightly lower than in a 30-ha plot at Vargalaiaar (148 species, Ayyappan \& Parthasarathy 1999). Singletons and doubleton species were considered rare and accounted for 44\% (41 species), 22\% (18 species) and 31.5\% (23 species) in EG, SEG and MD respectively, of the total numbers of species recorded in the study plots. The observation is comparable with the species rarity as studied in different areas of Western Ghats. e.g. by PAscal \& Pelissier (1996) - (40\%) or PARTHASARATHY \& KaRTHIKEYAN (1997) - (47\%).

Tree density $\left(\mathrm{ha}^{-1}\right)$ was high in $\mathrm{MD}$, intermediate in EG, and low in SEG, whereas basal area $\left(\mathrm{m}^{2} \mathrm{ha}^{-1}\right)$ was high in EG, intermediate in SEG, and low in MD. The observation of high tree density and low basal area in MD indicates the influence of anthropogenic disturbances. Being nearer to the human habitations and at low altitudes, these forests are first choice of the inhabitants and thus are prone to deforestation. The existence of gaps in the canopy, due to the disturbances, favors the rapid growth of young trees with low basal area. In contrast, the EG plot represents a mature community formed from trees with large girth, contributing a high basal area. 
The tree density recorded in EG forest in the present study, i.e. 515 trees ha ${ }^{-1}$, is high in comparison to some other EG forest studies: $482 \mathrm{ha}^{-1}$ in Courtallum reserve, Western Ghats (PARTHASARATHY \& KARTHIKEYAN 1997) and 419 ha $^{-1}$ also in Western Ghats (GHATE et al., 1998), but low with reference to 579 and $732 \mathrm{ha}^{-1}$ in giant evergreen forest of Middle Andaman (RAJKumar \& PARTHASARATHY 2008), $716 \mathrm{ha}^{-1}$ in southern Western Ghats (PARTHASARAthy 1999), 583 ha $^{-1}$ in Kalalad Mudanthurai Tiger reserve, Western Ghats (GANESH et al. 1996), 635 ha $^{-1}$ in southwest India (PASCAL \& Pelissier 1996), and $522 \mathrm{ha}^{-1}$ in MD forest in the present study. The basal area for the 3 forest types ranged between 35.4 and $43.2 \mathrm{~m}^{2} \mathrm{ha}^{-1}$, which is greater than $25.5 \mathrm{~m}^{2}$ $\mathrm{ha}^{-1}$ in Rio Xingu Brazil (CAMPBELl et al. 1992) and $27.4 \mathrm{~m}^{2} \mathrm{ha}^{-1}$ in Ecuador, Amazon (VALENCIA et al. 1994), but lower than $82.67 \mathrm{~m}^{2}$ ha $\mathrm{a}^{-1}$ on Reunion island (STRAsBerG 1996), as well as 45.59 and $47.93 \mathrm{~m}^{2} \mathrm{ha}^{-1}$ on Middle Andaman (RAJKUMAR \& PARTHASARATHY 2008). It is noteworthy that in our analysis we have considered only tree species that are over $30 \mathrm{~cm}$ in girth, unlike few other studies.

In all the 3 forest types, girth classes 30-60 and 60-90 cm exhibited higher species richness and diversity, and this can be attributed to the recruitment of new species from the nearby neighbouring communities. The tree girth class distribution (Fig. 3) revealed a decreasing number of trees with increasing girth class, and followed a reverse $\mathrm{J}$ pattern. The presence of a large number of juveniles relative to adults clearly indicates population stability (CONDIT et al. 1998) and natural regeneration of the forest, as younger individuals contributed low basal area, and fewer dominant older trees occupied much of the basal area in the community $(>210 \mathrm{~cm}$ girth class with basal area $>13 \mathrm{~m}^{2} \mathrm{ha}^{-1}(>30 \%)$ in the 3 forest types of NAI). Presence of a larger number of trees in lower girth classes is a sign of a good potential regeneration, and our results are more or less similar to the studies carried out in different forest stands of various regions, e.g. by SuKUMAR et al. (1992), NADKARNi et al. (1995), Lieberman et al. (1996), Parthasarathy \& Karthikeyan (1997), and Rajkumar \& Parthasarathy (2008).

The subplot analysis in 3 forest types showed the highest species richness (30) and diversity (4.7) in SEG, while the highest stem density (88) and basal area (8.7 $\mathrm{m}^{2}$ ) in EG (Table 1). Diversity was the highest in north-west subplots of EG (subplot 26) and MD (subplot 25), and in a north-east subplot of SEG (subplot 10). The high values observed in subplots 9 (for basal area and mean height) and 19 (for stem density) of EG are mainly contributed by Myristica andamanica and M. glaucescens, respectively. In SEG, high values recorded for stem density (subplot $23^{\text {rd }}$ ), basal area (subplot 17), and mean height (subplot 16), are due to the presence of Celtis wightii, Dipterocarpus gracilis, and Artocarpus chaplasha, respectively. Within MD, Diospyros oocarpa in subplots 12 and 16 (for tree density) and Pterocarpus dalbergoides in subplots 13 and 1 (for basal area and mean height) accounted for recording high values in the subplots. The subplot plant diversity values correlate with the 3-ha plot results that showed high diversity in SEG and basal area in EG. Also similar to 3-ha analysis, Myristica andamanica and Diospyros oocarpa were found to be key species in EG and MD subplots respectively.

In the 3 forest communities, a majority of species exhibited clumped distributional pattern, in contrast to the results of other tropical studies (Hou et al. 2004; 
Seidler \& Plotkin 2007, Lan et al. 2008, 2009). Random distribution is indicative of a disturbance factor (ARMESTO et al. 1986) that might have dispersed the species at different locations randomly. A clumped distribution is attributed to the dispersal syndrome of species, where species either lack a suitable dispersal agent or are inefficient in dispersing the seeds (RICHARDS 1996) to the new environment, and as a result, they grow in the same, parental niche, forming clumps or groups. Regular distribution in the present study is rare and is exhibited by only one species in EG. In the 3 forest types, $>70 \%$ of species showed clumped patterns, attributed to the existence of dense, closed canopy (except few areas of MD) that limits dispersal. Among the recorded families, Anacardiaceae and Sterculiaceae dominated in all the 3 forest types, showing a wide distributional pattern throughout NAI. The tree height distribution was similar in the 3 forest types, except a high percentage $(8 \%)$ of trees over $15 \mathrm{~m}$ tall in $\mathrm{EG}$, forming the upper layer of the canopy.

\section{CONCLUSIONS}

The species diversity and richness of the island ecosystem is different and unique, as compared with mainland. Islands harbor either highly diversified communities or poor communities, depending on the ecological and geographical conditions through which they have stabilized the community. The species richness, diversity, stand density and basal area of these islands show intermediate values in comparison with other forests. The analysis of vegetation descriptors in subplots indicated the spatial distribution and range of plant diversity levels that can be encountered on NAI. Within the 3-ha plot, plant diversity values varied between the subplots, indicating the influence of certain microhabitat factors, which needs further investigation. Though different methods were used to study the North Andaman vegetation (random survey, continuous large plot inventory, subplot level analysis, or girth class distribution analysis), all the results confirm that SEG is the most diversified community of NAI. Since many studies throughout the world have focused on wet evergreen forest, the EG of North Andaman can be compared with other studies, especially of Western Ghats. Analysis of 3-ha plot in 3 different forest types substantially contributed data on North Andaman site potentiality with reference to species richness and diversity, and adds it to the list of sites of high floristic diversity.

Acknowledgements: The present study is part of research carried out under Jai Vigyan Science and Technology Mission Project. Thanks are due to Project Director Dr. P.S. Roy and officials of the North Andaman Forest Department, for their guidance and assistance.

\section{REFERENCES}

Allen R. B., Lee. W. G., Rance. B. D. 1994. Regeneration in indigenous forest after eradication of Norway rats, Breaksea Island, New Zealand. New Zeal. J. Bot. 32: 429-439.

Armesto J. J., Mitchell J. D., Villagran C. 1986. A comparison of spatial patterns of trees in some tropical and temperate forests. Biotropica 18: 1-11. 
Ayyapan N., Parthasarathy N. 1999. Biodiversity inventory of trees in a large-scale permanent plot of tropical EG forest at Varagalaiar, Anamalais, Western Ghats, India. Biodivers. Conserv. 8: $1533-1554$.

Batalha M. A., Mantovani W., Mesquita Júnior H. N., De Rees M., Condit R., Crawley M., PacaLA S., Tilman D. 2001. Long term studies of vegetation dynamics. Science 293: 650-655.

Blasco F., Whitmore T. C., Gers C. 2000. A framework for the worldwide comparison of tropical woody vegetation types. Biol. Conserv. 95: 175-189.

Borcard D., Legendre P., Drapeau P. 1992. Partialling out the spatial component of ecological variation. Ecology 73: 1045-1055.

Bunyavejchewin S., Baker P. J., Lafrankie J. V., Ashton P. S. 2001. Stand structure of a seasonal dry evergreen forest at Huai Kha Khaeng Wildlife Sanctuary, Western Thailand. Nat. Hist. Bull. Siam Soc. 49: 89-106.

Campbell D. G., Stone J. L., Rosas JR. A. 1992. A comparison of the phytosociology and dynamics of three floodplain (varzea) forest of known ages, Rio Jurua, western Brazilian Amazon. Bot. J. Linn. Soc. 108: 213-237.

ChandrasheKara U. M., Ramakrishnan P. S. 1994. Vegetation and gap dynamics of a tropical wet evergreen forest in the Western Ghats of Kerala, India. J. Trop. Ecol. 10: 337-354.

Clark D. B., Clark D. A. J., Read. M. 1998. Edaphic variation and the mesoscale distribution of tree species in a neotropical rain forest. J. Ecol. 86: 101-112.

Condit R. 1995. Research in large, long-term tropical forest plots. Trends Ecol. Evol. 10: 18-22

Condit R., Sukumar R., Hubbell S. P., Foster R. B. 1998. Predicting population trends from size distributions: a direct test in a tropical tree community. Am. Nat. 152: 495-509.

Cотtam G., Curtis J. T. 1956. The use of distance measurement in phytosociological sampling. Ecology 37: 451-460.

Coyne J. A., OrR H. A. 2004. Speciation. Sinauer Associates Inc, Sunderlands.

Debski I., Burslem, D. F. R. P., Lamb D. 2000. Ecological processes maintaining differential tree species distributions in an Australian subtropical rain forest: implications for models of species coexistence. J. Trop. Ecol. 16: 387-415.

Devaraj P. 2001. Forests of Andaman Islands. International Book Distributors, Dehradun.

Elaine R. H., Legendre P., Condit R. 2004. Factors affecting community composition of forest regeneration in deforested, abandoned land in Panama. Ecology 85: 3313-3326.

Empson L., Flenley J., Sheppard P. 2002. A dated pollen record of vegetation change on Mayor Island (Tuhua) throughout the last 3000 years. Global Planet. Change. 33: 329-337.

Ganesh T., Ganesan R., Soubadradevy M., Davidar P., Bawa K. S. 1996. Assessment of plant biodiversity at a mid-elevation evergreen forest of Kalalad Mudanthurai Tiger reserve, Western Ghats of India. Curr. Sci. India. 71: 379-392.

Gaston K. J. 1996. Biodiversity: A biology of numbers and difference. p. 396, Blackwell Science, Oxford.

Ghate U., Joshi N. V., Gadgil M. 1998. On the patterns of tree diversity in the Western Ghats of India. Curr. Sci. India 75: 594-603.

Grant V. 1981. Plant speciation. 2nd ed., Columbia University Press, New York.

Gunatilleke C. V. S., Gunatilleke I. A. U. N., Ethugala A. U. K., Esufali S. 2004. Ecology of Sinharaja rain forest and the forest dynamics plot in Sri Lanka's Natural World Heritage Site, WHT Publications, Colombo.

HiLl M. O. 1973. Diversity and evenness: a unifying notation and its consequences. Ecology 54: 427-432.

Hitendra P., Chauhan N., Porwal M. C., Roy P. S. 2004. Phytosociological observations on tree species diversity of Andaman Islands. Curr. Sci. India. 87: 799-806.

Hou J. H., Mi X. C., Liv C. R., MA K. P. 2004. Spatial patterns and associations in a Quercus Betula forest in northern China. J. Veg. Sci. 15: 407-414. 
Hubbell S. P., Foster R. B., Obrien S. T., Harms K. E., Condit R., Wechsler B., Wright S. J., De LAO S. L. 1999. Light-gap disturbances, recruitment limitation, and tree diversity in a neotropical forest. Science 283: 554-557.

Jacobs J. D., Headley A. N., Maus L. A., Mode W. N., Simms É. L. 1997. Climate and vegetation of the Interior Lowlands of Southern Baffin Island: long-term stability at the low arctic limit. Arctic 50: 167-177.

KrupNick G. A., Kress W. J. 2003. Hotspots and ecoregions: A test of conservation priorities using taxonomic data. Biodivers. Conserv. 12: 2237-2253.

Lan G., Hu Y., Cao M., Zhu H., Wang H., Zhou S., Deng X., Cui J., Huang J., Liu L., Xu H., Song J., He Y. 2008. Establishment of Xishuangbanna tropical forest dynamics plot: species compositions and spatial distribution patterns. J. Plant Ecol. 32: 287-298 (in Chinese with English abstract).

Lan G., Zhu H., Cao M., Hu Y., Wang H., Deng X, Zhou S., Cui J., Huang J., He Y., Liu L., Xu H., SonG J. 2009. Spatial dispersion patterns of trees in a tropical rainforest in Xishuangbanna, Southwest China. Ecol. Res. 24:1117-1124.

Lee H. S., Davies S. J., Lafrankie J. V., Tan S., Yamakura T., Itoh A., Ashton P. S. 2002. Floristic and structural diversity of 52 hectares of mixed dipterocarp forest in Lambir Hills National Park, Sarawak, Malaysia. J. Trop. For. Sci. 14: 379-400

Lieberman D., Lieberman M., Peralta R., Hartshorn G. S. 1996. Tropical forest structure and composition on a large-scale altitudinal gradient in Costa Rica. J. Ecol. 84: 137-152.

MacArthur R. H., Wilson E. O. 1967. The theory of island biogeography. Princeton University Press, Princeton, New York.

Manokaran N., La Frankie Jr. J. V., Kochummen K. M., Quah E. S., Klahn J. E., Ashton P. S., Hubbell S. P. 1990. In: Methodology for the fifty hectare research plot at Pasoh Forest Reserve (Chan H.T., Ed), Research Pamphlet, vol. 104, pp. 1-69, Forest Research Institute of Malaysia, Kepong, Malaysia.

Murphy P. G., Lugo A. E. 1986. Ecology of dry forest. Annu. Rev. Ecol. Syst. 17: 67-88.

Myers W. L., Patil G. P., Taillie C. 1995. Comparative paradigms for Biodiversity Assessment. In: Measuring and Monitoring Biodiversity in Tropical and Temperate Forests (BoyLE T. J., Boontawee B., Eds), Proceedings of the IUFRO Symposium, Chiang - Mai, Thailand, 27 VIII - 02 IX 1994, pp. 67-85, CIFOR, Bogor, Indonesia.

NAdKarni N. M., Matelson T. J., Haber W. A. 1995. Structural characteristics and floristic composition of a Neotropical cloud forest, Monteverde, Costa Rica. J. Trop. Ecol. 11: 481-495.

NEGI H. R. 2001. Diversity and dominance of liverworts of Chopta-Tunganath in the Garhwal Himalaya. Int. J. Ecol. Environ. Sci. 27: 13-21.

Parthasarathy N. 1988. A phytogeographic analysis of the flora of Kalakad reserve forest Western Ghats. J. Indian Bot. Soc. 67: 342-345.

PARTHASARATHY N. 1999. Tree diversity and distribution in undisturbed and human-impacted sites of tropical wet evergreen forest in southern Western Ghats, India. Biodivers. Conserv. 8: 1365-1381.

Parthasarathy N., Karthikeyan R. 1997. Biodiversity and population density of woody species in a tropical evergreen forest in Courtallum reserve forest, Western Ghats, India. Trop. Ecol. 38: 297-306.

Parthasarathy N., Arthur Selwyn M., Udayakumar M. 2008. Tropical dry evergreen forests of peninsular India: ecology and conservation significance. T.C.S. 1: 89-110.

Pascal J. P., Pelissier R. 1996. Structure and floristic composition of tropical evergreen forest in southwest India. J. Trop. Ecol. 12: 191-214.

Pascal J. P., Ramesh B. R., Bourgeon G. 1998. The Kan Forests of the Karnataka Plateau (India) structure and floristic compositions. Trends in the changes due to their exploitation. Trop. Ecol. 29: 9-23.

Prasad R. C. P., Reddy C. S., Dutt C. B. S. 2007. Phytodiversity assessment of tropical rainforest of North Andaman Islands, India. Res. J. For. 1: 27-39. 
Prasad R. C. P., Reddy C. S., Dutt C. B. S. 2008. Phytodiversity zonation in North Andaman Islands, India, using remote sensing, GIS and phytosociological data. Res. J. Environ. Sci. 2: 1-12.

Prasad R. C. P., Sringeswara A. N, Reddy C. S., Nagabhatla N., Rajan K. S, Giriraj A., Murthy M. S. R., Raza S. H., Dutt C. B. S. 2009. Assessment of forest fragmentation and species diversity in North Andaman Islands (India): a geospatial approach. I. J. E. D. 13: 35-48.

Price J. P., Wagner L. WarRen. 2004. Speciation in Hawaiian angiosperm lineages: cause, consequence, and mode. Evolution 58: 2185-2200.

Rajkumar M., Parthasarathy N. 2008. Tree diversity and structure of Andaman Giant Evergreen Forests, India. Taiwania 53: 356-368.

Richards P. W. 1996. The tropical rain forest an ecological study. (Richards P. W. with contributions by Walsh R. P. D, Baillie I. C. Greig-Smith P., Eds), 2ed edition, Press Syndicate of the University of Cambridge, Cambridge.

Roy P. S., Padalia H., Chauhan N., Porwal M. C., Biswas S., Jagdale R. 2005. Validation of geospatial model for biodiversity characterization at landscape level - a study in Andaman \& Nicobar Islands, India. Ecol. Model. 185: 349-369.

Ruokolainen K., Linna A., Tuomisto H. 1997. Use of Melastomataceae and pteridophytes for revealing phytogeographical patterns in Amazonian rain forests. J. Trop. Ecol. 13: 243-256.

Seidler T. G., Plotkin J. B. 2007. Seed dispersal and spatial pattern in tropical trees. PLoS Biol. 4: 2132-2137.

Shannon C. E., Weaver W. 1963. The mathematical theory of communication. University of Illinois Press, Urbana.

Simpson E. H. 1949. Measurement of diversity. Nature 163: 688.

SORENSEN T. 1948. A method of establishing groups of equal amplitude in plant sociology based on similarity of species and its application to analyses of the vegetation on Danish commons. Biol. Skrif. 5: 1-34.

Stewart G. H. 1986. Forest dynamics and disturbance in a beech/hardwood forest, Fiordland, New Zealand. Vegetatio 68: 115-126.

STRASBERG D. 1996. Diversity, size composition and spatial aggregation among trees on a one-hectare rainforest plot at a La Réunion. Biodivers. Conserv. 5: 825-840.

Sukumar R., Dattaraja H. S., Suresh H. S., Radhakrishnan J. V., Vasudeva R., Nirmala S., Joshi N. V. 1992. Long-term monitoring of vegetation in a tropical deciduous forest in Mudumalai, Southern India. Curr. Sci. India. 62: 608-616.

Terborgh J., Foster R. B., Nunez P. V. 1996. Tropical tree communities: a test of the nonequilibrium hypothesis. Ecology 77: 561-567.

Thompson J., Brokaw N., Zimmerman J. K., Waide R. B., Everham III E. M., Lodge D. J., Taylor C. M., Garcia- Montel D., Fluet M. 2002. Land use history, environment, and tree composition in a tropical forest. Ecol. Appl. 12: 1344-1363.

Tuomisto H., Poulse, A. D., Ruokolainen K., Moran R. C., Quintana C., Celi J., Canas G. 2003. Linking floristic patterns with soil heterogeneity and satellite imagery in Ecuadorian Amazonia. Ecol. Appl. 13: 352-371.

Valencia R., Balslev H., Mino G. C. P. Y. 1994. High tree alpha-diversity in Amazonian Ecuador, Biodivers. Conserv. 3: 21-28.

White M. J. D. 1978. Modes of speciation. W. H Freeman and Company, San Francisco.

Wikramanayake E. D., Dinerstein E., Loucks C. J., Olson D. M., Morrison J., Lamoreux J., McKNIGHT M., Hedao P. 2002. Terrestrial Ecoregions of the Indo-Pacific: A Conservation Assessment. Island Press, Washington, DC.

Zimmerman J. K., Everham E. M. I., Waide R. B., Lodge D. J., Taylor C. M., Brokaw N. V. L. 1994. Responses of tree species to hurricane winds in subtropical wet forest in Puerto Rico: implications for tropical tree life histories. J. Ecol. 82: 911-922. 